\title{
Group Education Model Improving the Knowledge of School Age Children in Protecting of Sexual Violence
}

\author{
I Ketut Labir ${ }^{1 *}$, Ni Luh Kompyang Sulisnadewi², I Nyoman Ribek ${ }^{3}$
}

${ }^{123}$ Nursing Department, Health Polytechnic, Ministry of Health, Denpasar, Bali

A R T I C L E I N F O

Article history:

Received 15 August 2019

Received in revised Form 29 September 2019

Accepted 18 October 2019

Available online 29

November 2019

Keywords:

Education - Elementary School Age Knowledge Efforts to Protect

Themselves from Sexual Violence

\begin{abstract}
A B S T R A C T
Cases of sexual violence and abuse in Indonesia are increasingly common. Not only in adults, children are now victims. Some cases of victims or perpetrators involve underage children. Many parents feel taboo to talk about early childhood education with children. This causes children not to get information that is supposed to protect themselves from sexual violence. Need to do various efforts to provide education to children about knowledge to protect themselves from sexual violence. The purpose of this study was to determine the effect of sexual violence education on children on efforts to protect from sexual violence. This study uses pre-experimental design with approach pretest-posttest design. The number of samples is 195 children taken by purposive sampling technique. Analyze data using different Wilcoxon Signed Rank test with $95 \%$ significance level, $p \leq(0.05)$. The results showed that the average age of the respondents was 10.2 years and most of the men were $52.8 \%$. Before giving education, the average score of respondents' knowledge about efforts to protect themselves from sexual violence was 6.7 and increased to 7.79 after giving education. There is a difference in knowledge about efforts to protect themselves from sexual violence before and after being given education ( $p$ value $\leq 0.001 ;<\alpha=0.05$ ). It is recommended that the provision of information about sexual violence be given regularly by teachers and parents.
\end{abstract}




\section{Introduction}

Cases of violence and sexual abuse in Indonesia are increasingly common. Not only in adults, children are now victims. Some cases of victims or perpetrators involve underage children. Sexual violence in children is the highest level of violence compared to physical and psychological violence.

WHO estimated that over than 150 million children and adolescents under 18 years old have experience sexual violence in one form or another. Sexual abuse is a global health and human right problem and has been reported to commonly effect girl more than boys. About 1 in 4 girls and 1 in 10 boys have experienced sexual violence.(1)

About $15 \%$ to $25 \%$ of women and $5 \%$ to $15 \%$ of men experience sexual abuse when they are children in North America. Most sexual harassment actors are people who are known by their victims; about $30 \%$ are families of the child, most often brothers, fathers, uncles, or cousins; around $60 \%$ are other acquaintances such as 'friends' from family, caregivers, or neighbors, foreigners are offenders around $10 \%$ in cases of child sexual abuse. Most child sexual abuse is carried out by men; studies show that women commit $14 \%$ to $40 \%$ of reported violations of boys and $6 \%$ of reported violations against women. Most offenders who sexual abuse children before puberty are pedophiles, although some perpetrators do not meet clinical diagnosis standards for pedophilia (2)

According to the Indonesian Child Protection Commission (KPAI) in 2011 alone there were 2,275 cases of violence against children, 887 of them were child sexual violence. In 2012 there were 3,871 cases of violence against children, 1,028 of which included sexual violence against children. In 2013, of 2,637 violence against children, 48 percent or about 1,266 were sexual violence against children (3) Based on data and information from the National Commission for Children, throughout 2016 there were 625 cases. The details, cases of physical violence were 273 cases (40\%), psychological violence 43 cases (9\%), and most were cases of sexual violence 309 cases (51\%), Based on the scene of violence against children in the closest family environment 40\%, environment social 52\%, school environment 5\% (4) KPAI Commissioner Jasra Putra revealed, data showed that it found 218 cases of child sexual violence in 2015. While in 2016, KPAI recorded 120 cases of sexual violence against children. Then in 2017, there were 116 cases (5)

Violence against children can have short-term effects such as physical problems, emotional disturbances or behavioral changes to developmental disorders, or even long-term disabilities. While other severe effects can include unwanted pregnancies, sexually transmitted infections, disorders of reproductive organs, and deep psychological trauma with all the consequences. Children must be protected from all possible violence, especially sexual violence, because they are in the process of growing up. Preventive and curative efforts refer to the concept that all must be given in full, comprehensive and comprehensive, not taking sides with a group or group of children, carried out with the best interests of the child by remembering their right to live and develop, and respecting their opinions (6) Many parents feel taboo to talk about early childhood education with children. This causes children not to get information that is supposed to protect themselves from sexual violence. Based on this background, a variety of knowledge is needed to provide education to children about knowledge to protect themselves from sexual violence.

\section{Methods}

This study used pre-experimental design with aapproach pretest-posttest group design, which held at SD 1 Cemagi, SD 1 Prerenan, SD 2 Prerenan Mengwi District. Data collection was held from August to September 2018. The population in this study were elementary school children in the Mengwi subdistrict. The sampling technique was purposive sampling, with a total sample obtained during the study as many as 195 people.

Analysis of the variables in this study was carried out in univariate and bivariate. analysis was Univariate used to explain the variable characteristics of respondents which included age, and gender and the description of respondents' knowledge about sexual violence before and after implementing education. All data were analyzed with a significance level of $95 \%(\alpha=0.05)$. Bivariate analysis is used to determine the relationship or significant difference between two variables. The results of the data normality test found that the data were distributed abnormally so that bivariate analysis was used different Wilcoxon Signed Rank test with 95\% significance level, $\mathrm{p} \leq(0.05)$. 


\section{Result And Discussion}

Characteristics of respondents are school-age children identified by age, and gender. Numerical data were analyzed so that the average, median, and standard deviation values were obtained. Categorical data were analyzed and the results were in the form of percentages. The results of the analysis of each variable are shown in the following table.

Table 1. Distribution of Respondents According to The Characteristics of Respondents (Age)

\begin{tabular}{cccc}
\hline Variable & Mean & SD & Minimum-maximum \\
\hline Umur $(\mathrm{n}=195)$ & 10.2 & 0.953 & $8-13$ \\
\hline
\end{tabular}

Based on Table 1 the average age of respondents is 10.2 years, with standards deviation of 0.953 years. The youngest is 8 years old and the oldest is 13 years old.

Table 2. Distribution of Respondents by Gender in Mengwi Sub district in 2018

\begin{tabular}{lccc}
\hline & Variable & \multicolumn{2}{c}{ (n= 195) } \\
\cline { 2 - 4 } & Sex & f & \% \\
\hline Male & & 102 & 52.8 \\
Women & & 92 & 47.2 \\
\hline
\end{tabular}

Based on Table 2 it can be seen that the majority of respondents were male by $52.8 \%$ and $47.2 \%$ female.

Table 3. Distribution of Responden Knowledge

\begin{tabular}{lccc}
\hline \multicolumn{1}{c}{ Variable } & Mean & SD & Minimum-Maximum \\
\hline \multicolumn{1}{c}{ Knowledge $(\mathbf{n}=\mathbf{1 9 5})$} & & & \\
\hline Pre Test & 6.7 & 1,944 & $2-10$ \\
Post Test & 7.79 & 1,853 & $3-10$ \\
\hline
\end{tabular}

Table 3 shows that before giving education, the average score of respondents' knowledge about efforts to protect themselves from sexual violence was 6.7 with a standard deviation of 1.944 . The lowest score of 2 and the highest score is 10 . After giving education, the average score of respondents' knowledge about efforts to protect themselves from sexual violence is 7.79 with a standard deviation of 1.853 Lowest Score 3 and the highest score is 10.

Table 4. Results of Wilcoxon Signed Ranks Test

\begin{tabular}{llc}
\hline & & $\mathbf{N}$ \\
\hline & Negative Ranks & $25^{\mathrm{a}}$ \\
Score Post Test - Pre Test Score & Positive Ranks & $112^{\mathrm{b}}$ \\
& Ties & $58^{\mathrm{c}}$ \\
\cline { 2 - 3 } & \multicolumn{1}{c}{ Total } & $\mathbf{1 9 5}$ \\
\hline
\end{tabular}

Based on Table 4 shows that of 195 people sampled, scores post test were lower than pre test (negative rank) of 25 people, the score post test was higher than the pre test as many as 112 people, and the value was the pre test same as the post test as many as 58 people.

Table 5. Statistical Test Results Wilcoxon Signed Ranks of Responden Knowledge Tests

\begin{tabular}{ccc}
\hline Variable & $\mathbf{Z}$ & $\boldsymbol{p}$ Value \\
\hline Knowledge & $-6,681$ & $0,000^{*}$ \\
\hline
\end{tabular}


The results of the analysis in Table 5 show there are differences in knowledge about efforts to protect themselves from exempt violence before and after being given education ( $\mathrm{p}$ value $=0,000 ;<\alpha=$ $0.05)$.

The average age of respondents is 10.2 years, with a standard deviation of 0.953 years. The youngest is 8 years old and the oldest is 13 years old. Based on Piaget's cognitive development theory, at this stage logical thinking replaces intuitive thinking. The concept that was originally vague and unclear, has now become concrete. Children have been able to think rationally and carry out certain logical activities, although they are still limited to concrete objects and in concrete situations. Children have been able to demonstrate the skills of conversion, classification, addition, subtraction, and several other abilities that are very needed by children in learning basic knowledge in school. The way of thinking is less egocentric which is characterized by large concentration, which is able to show more than one dimension and also connect with one another. Towards the end of this period or stepping on pre-teens, cognitive abilities are increasing (7). In this study, most of the respondents were $52.8 \%$ and $47.2 \%$ were female. Men perceive themselves more objectively, they will be more mature in thinking and behaving

Age and sex factors are factors that need to be considered in the occurrence of sexual violence. Sexual violence (sexual abuse) is a prominent case that occurs in children. In the records of the Indonesian Child Welfare Foundation in 1992-2002 there were 2,611 cases (65.8 percent) out of 3,969 cases of sexual violence experienced by children under the age of 18 years. Of that amount, 75 percent of the victims are girls. The prominent cases were mainly rape (42.9 percent) with the incident occurring at home (35.7 percent). Based on Integrated Crisis Center data from Ciptomangunkusumo Hospital, victims of child sexual abuse are more prevalent in children who are not in school, children who are sitting in kindergarten and elementary school (Viciawati, 2008). Seeing these facts and data, education about sexual violence is very important to do early on, both for boys and girls, even though the data show more victims of violence in girls.

The results of data analysis showed that from 195 samples, the score post test was lower than the pre test ( negative rank) of 25 people, the score post test was higher than the pre test as many as 112 people, and the pre test score was the same as the post test as many as 58 people. Most of the scores post test respondent's were greater than the score pre test. This is in accordance with the theory of learning that will make someone know what has been informed. Even though there are still scores that are fixed and around $13 \%$ of the pre test score is lower than the post test, this can be caused by various factors that affect the learning process including the concentration of answering questions and seriousness and listening to the material provided that cannot be controlled properly .

Before giving education, the average score of respondents' knowledge about efforts to protect themselves from sexual violence was 6.7 and increased to 7.79 after giving education. The pre test score is lower than post test is likely caused by a lack of information obtained about how to protect yourself from sexual violence. May be also because they feel taboo or embarrassed to talk about it.

Children and young people are not receive enough adequate preparation for a safe and satisfying adult sexual life. Open discussion of sexual matters with trusted adults is usually absent at the very time when it is most needed. Added with the pervasive, confusing and conflicting (and predominantly negative) messages received by children about sexuality and gender. These may contribute to creating and sustaining vulnerability to coercion, abuse and exploitation. Effective sexuality education is therefore essential in order to redress this balance.

Group education provided to respondents has increased the score of their knowledge about sexual violence and efforts to protect themselves from sexual violence. This is in accordance with the theory (9) which states that knowledge is the result of human sensing or the result of knowing someone to an object through their senses.

The results of the analysis show that there are differences in knowledge about efforts to protect themselves from sexual violence before and after being given education ( $\mathrm{p}$ value $=0,000 ;<\alpha=0.05$ ), which means that $\mathrm{HO}$ is rejected so that there is an influence of child sexual violence education on children's knowledge about protecting themselves from sexual violence. Educational effort is a learning process to know more about something. The increase in knowledge that occurs after being given education is one aspect of the ability achieved by respondents as a result of the learning process. The learning process in health education is a mechanism or process of changing the ability of subjects to learn with the expected output is the ability as a result of changes in behavior of the target students.

The results of this study are supported by research which found the application of AMANJARI game simulations in five primary schools in the area proved to increase students' knowledge of how to protect themselves and prevent sexual violence, so as to reduce the impact of sexual violence on children in the Kediri Region. 
Other research results that support is research by that found Modules of the "Neherta" model proved to be effective increasing the average value of knowledge and elementary school-aged children's assertiveness in West Sumatra. The module of "Neherta" model is one of the best intervention modules to increase knowledge and assertiveness of school-age children. The learning method of this model based on school-age characteristics which are very glad to play and sing. In this model, uses presentations, story discussions, pictorial sketches, video, role play, leaflet and singing with a Minangkabau lyric as the learning media "Neherta"

The educational activities provided are packaged attractively so that the children feel enthusiastic about participating in the activity. The education provided was conceptualized by playing, singing, watching videos and having fun. At the beginning of student activities and invited to sing and play together. There is also a guide dissemination activity that contains pictures and inserted messages to be careful of strangers who suddenly give them food and hold sensitive parts of their bodies. The students must also dare to say no and shout to strangers who want to kiss, hug, and even touch their sensitive body parts. Video screening of Si Komal also provides education to students to be more aware that the dangers of sexual violence to children are around them. In this 10-minute video, this interestingly presented one invites children not to believe easily with strangers and even the closest people who lure with food or gifts and try to harass their children. Parents or teachers must be friends so that if their children are victims of sexual abuse, their children dare to tell stories and are not afraid or embarrassed

After giving education, there is an increase in target knowledge of 1.09 points. This can be influenced by the delivery of material carried out interestingly, using video and smart books "I am able to guard myself" and invite children to sing songs about body parts that must be protected.

\section{Conclussion}

The average age of respondents is 10.2 years and most are male. Before giving education, the average score of respondents 'knowledge about efforts to protect themselves from sexual violence was 6.7. After giving education, the average score of respondents' knowledge about efforts to protect themselves from sexual violence increased to 7.79. There is a difference in knowledge about efforts to protect themselves from sexual violence before and after being given education.

\section{Reference}

Ferdianto. Darurat Nasional Kejahatan Seksual Anak [Internet]. 2009. Available from: http://news.metrotvnews.com/peristiwa/1bVY2gaN-2016-tahun-darurat-nasional-kejahatanseksual-ana

Gordon P. 3. Sexuality education and the prevention of sexual violence. Prot Child from Sex violence [Internet]. 2011;175-85. Available from: https://www.coe.int/t/dg3/children/1in5/Source/PublicationSexualViolence/Gordon.pdf

IDAI. Mengajari Kewaspadaan Kekerasan Seksual Pada Anak [Internet]. 2016. Available from: http://www.idai.or.id/artikel/seputar-kesehatan-anak

KPAI. Kekerasan pada anak tahun meningkat [Internet]. 2016. Available from: Kekerasan pada anak tahun meningkat

Lestari P, Zahro SF, Sugiharti W, Universitas B, Pgri N, Ahmad JKH, et al. Simulasi Permainan AMANJARI ( Aku Mandiri Jaga Diri ) sebagai Mitigasi Sosial Anti Kekerasan Seksual pada Anak di Lima Sekolah Dasar Wilayah Kediri The Simulation Game AMANJARI ( I Independent Keep My Self ) Social Mitigation of Sexual Violence on Childre. 2015;61-6.

Notoatmodjo S. Promosi Kesehatan dan Ilmu Perilaku. Jakarta: Rineka Cipta; 2007.

Nurdin Y, Neherta M, Meri D. The effectiveness of "neherta" model as primary prevention of sexual abuse against primary school children in west sumatera indonesia 2017. Indian J Public Heal Res Dev. 2018;9(10):446-52.

Ogunjimi AI, Abadio De Oliveira W, Maria E, De Vasconcelos R, Angelica M, Silva I. Child Sexual Abuse Prevention. J Nurs UFPE line. 2017;11(11):4469-82. 
Setiawan D. Tahun 2017, KPAI Temukan 116 Kasus Kekerasan Seksual Terhadap Anak. [Internet]. 2017. Available from: http://www.kpai.go.id/berita/tahun-2017

Soetjiningsih. Pertumbuhan dan perekembangan anak. Jakarta: EGC; 2014.

Yudasmara. Penanganan Kekerasan Seksual pada Anak [Internet]. 2016. Available from: https://loveindonesiachildren.wordpress.com 